\title{
Fruits and vegetables intake and its subgroups are related to depression: a cross-sectional study from a developing country
}

\author{
Elham Baharzadeh ${ }^{1}$, Fereydoun Siassi ${ }^{{ }^{*}}$, Mostafa Qorbani ${ }^{2}$, Fariba Koohdani ${ }^{3}$, Neda Pak ${ }^{4,5}$ and Gity Sotoudeh ${ }^{{ }^{*}}$
}

\begin{abstract}
Background: The association of fruits and vegetables (FV) specific subgroups consumption and depression has not been investigated in healthy adult populations. Therefore, the aim of our study was to determine the relationship between intake of $\mathrm{FV}$ as well as their subgroups and depression.

Methods: This cross-sectional study was conducted on 400 women attending healthcare centers. The scores of depression, anxiety, and stress were measured using the 21 -item depression, anxiety and stress scales questionnaire. The participants' anthropometric and physical activity data were collected and the 147-item semi-quantitative FFQ was used for estimating the FV intake.

Results: After adjustment for confounding variables, the participants in the lower quartiles of total FV, total vegetables, total fruits, citrus, other fruits and green leafy vegetables intake were more likely to experience depression compared to those in the higher quartiles ( $p$ trend $<0.03$ ).

Conclusion: Our findings suggest that higher intake of total FV and some of its specific subgroups might be associated with depression.
\end{abstract}

Keywords: Depression, Diet, Fruits, Vegetables, Women

\section{Background}

According to the World Health Organization's (WHO) report, depression is a common mental disorder. Globally, more than 300 million people of all ages suffer from depression. This disease is a major contributor to the overall burden of disease and is the leading cause of disability worldwide. Women are more affected by depression than men [1]. In Iran, the prevalence of mental disorders is $23.4 \%$ (27.5\% in women and $19.2 \%$ in men), with the prevalence of depression being $10.3 \%$ (11.4\% in women and 9.3\% in men) [2]. Several studies have investigated the relationship between fruits and vegetables (FV)

\footnotetext{
*Correspondence: siassif@tums.ac.ir; gsotodeh@tums.ac.ir

1 Department of Community Nutrition, School of Nutritional Sciences and Dietetics, Tehran University of Medical Sciences, Hojatdost Street, Naderi Street, KeshavarzBlv., Tehran, Iran

Full list of author information is available at the end of the article
}

intake and development of depression, but the results are inconsistent. Cross-sectional studies have reported an inverse association between the consumption of FV and depression [3-7]. Some prospective cohort studies have also found that less FV consumption was associated with a higher risk of depression [8, 9]. A meta-analysis study revealed that consumption of $\mathrm{FV}$ is inversely related to the risk of depression [10]. Contrary to these results, some cross-sectional studies did not find any relationship between FV consumption and depression [11-13]. Further, in a prospective cohort study, it was found that only vegetables proved to be protective against symptoms of depression, while this effect was not found for fruits [14]. In some cross-sectional studies, an association was found between high consumption of vegetables [15], green leafy vegetables [16], and lower odds of depression, but no relationship was found for fruits $[15,16]$. Nevertheless,

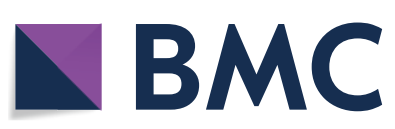

(c) The Author(s) 2018. This article is distributed under the terms of the Creative Commons Attribution 4.0 International License (http://creativecommons.org/licenses/by/4.0/), which permits unrestricted use, distribution, and reproduction in any medium, provided you give appropriate credit to the original author(s) and the source, provide a link to the Creative Commons license, and indicate if changes were made. The Creative Commons Public Domain Dedication waiver (http://creativecommons.org/ publicdomain/zero/1.0/) applies to the data made available in this article, unless otherwise stated. 
for vegetable intake, no association was found in other studies $[17,18]$.

Oxidative stress [19,20] and inflammation [21] are directly associated with the chance of depression. FV are rich in antioxidants and anti-inflammatory components, which may have beneficial effects in the prevention of depression [17]. Moreover, in FV, there are vitamins, especially folate, B6, C, E, and minerals, including calcium, iron, magnesium, potassium, dietary fiber and phytochemicals especially polyphenols. Vitamin E, C, and polyphenols, which have antioxidant properties, can reduce the oxidative stress. Most of the mentioned nutrients in FV may reduce inflammation, thereby reducing the risk of depression [22, 23]. In addition, FV-rich diets may increase the level of brain-derived neurotrophic factor (BDNF) which is an important protein for neural development and synaptic plasticity. Its low level will result in low mental health including depression [22].

Subgroups of FV have different contents of nutrients, fiber, antioxidants and phytochemicals [24]. Therefore, they may not affect the risk of depression equally. Therefore, it is better to evaluate individual FV or their specific subgroups.

Although the relationship between the intake of FV and depression has been reported in some studies, the specific subgroups of FV and their possible association with depression in apparently healthy population have remained understudied. A cross-sectional study found an inverse relationship between consumption of tomato, as well as tomato products and depression in elderly population [25]. Another cross-sectional study reported that higher consumption of raw FV predicted better mental health. However, this study was only limited to 18-25-year-old subjects [26]. To the best of our knowledge, apart from the mentioned study, no study has investigated the association of intake of FV subgroups and depression in healthy adult populations. Therefore, the aim of our study was to determine the relationship between the consumption of FV, as well as their specific subgroups and depression.

\section{Methods}

\section{Subjects}

This cross-sectional study was conducted on 400 women attending eight health centers in Khorramabad, Iran from May to October 2017. The inclusion criteria were ages 20-49 years, at least fifth grade elementary education, and body mass index of $18.5-34.9 \mathrm{~kg} / \mathrm{m}^{2}$. On the other hand, the exclusion criteria were pregnancy and lactation, diagnosis of depression by a psychiatrist within a year prior to the start of the study, currently taking an antidepressant medication or in the past year, and use of tobacco or alcohol at least once a week. Women with diagnoses such as diabetes, cardiovascular disease, cancer, hypertension, kidney and liver disease, hyperthyroidism, epilepsy and MS, regular use of any medication or following special diet were excluded from the study. The objective and protocol of the study were explained to the participants, and informed consent was obtained from them before the study. The Ethics Committee of Tehran University of Medical Sciences approved the protocol of this study.

\section{Assessment of depression status}

The Depression, Anxiety, Stress Scales (DASS, 21-items) questionnaire was used to measure the score of depression. This questionnaire was provided by Lovibond in 1995, which was validated by Afzali et al. for Iran [27, 28]. In the short form of the DASS questionnaire, for each subscale of depression, anxiety and stress, 7 questions have been presented. Individuals responded to each question based on to what extent that item applied to them during the last week (from 0 to 3 : not at all, to some degree, to a considerable degree and very much, respectively). The scores on the DASS-21 were multiplied by 2 to calculate the final score. Based on the total score of depression, the subjects were divided into five groups of normal (0-9), mild (10-13), moderate (14-20), severe (21-27), and very severe $(>27)$ depression. However, due to the limited number of cases in some groups, they were simply divided into two groups of normal $(<10)$ and depressed $(\geq 10)[29]$.

\section{Anthropometric and physical activity assessment}

Weight was measured with minimal clothing and without shoes by a digital scale (Seca 813 , Germany) with a measurement accuracy of $100 \mathrm{~g}$. Their height was measured without shoes to the nearest $0.5 \mathrm{~cm}$ with a gauge. To calculate the body mass index (BMI), the weight was divided by the square of height $\left(\mathrm{kg} / \mathrm{m}^{2}\right)$. The International Physical Activity Questionnaire (IPAQ) - short formwas used to assess the physical activity of the participants [30]. Inquiries were made regarding vigorous and moderate activity and walking for at least $10 \mathrm{~min} /$ day during the previous 7 days. To calculate the activity, the duration and frequency of activity days were multiplied by the metabolic equivalent task value of the activity. The sum of the scores was calculated as the total physical activity per week.

\section{Dietary assessment}

The usual dietary intake during the past year was assessed using a validated semi-quantitative food frequency questionnaire (FFQ) which included 147 food items [31]. In addition, some questions related to local spices and vegetables were added to the questionnaire. Finally, the 
number of questions reached 161 questions. The participants were asked to report their frequency of consumption of each food item during the previous year on a daily, weekly, or monthly basis. For estimating the daily food intake, the information of the FFQ was converted to g/day. The food items were analyzed for their energy and nutrients content using the Nutritionist IV software (First Databank, San Bruno, CA), modified for Iranian foods. The software database is drawn from United States Department of Agriculture (USDA) [32] food composition tables [33].

FV was divided into specific groups including cruciferous vegetables, green leafy vegetables, other vegetables, berries, citrus fruits, and other fruits based on previous studies [34, 35]. The Healthy Eating Index (HEI-2015) score [36] summarizes the consumption of 13 foods or nutrients including total fruits, whole fruits, total vegetables, greens and beans, whole grains, dairy products, total protein foods, seafood and plant proteins, fatty acids, refined grains, sodium, added sugars, and saturated fats. Each component was scored on a scale of $0-5$ or 0-10. Similar to another study [24], we excluded FV when calculating the HEI score.

\section{Statistical analysis}

Data analysis was performed using the SPSS version 16 (SPSS Inc.). The Kolmogorov-Smirnov test was used to evaluate the data normality. The data with an abnormal distribution were logarithmically transformed for statistical analyses. The geometric mean (standard error of mean) was calculated for the transformed data. The independent $t$ test was employed to compare the quantitative variables between the two groups (depressed and healthy subjects). The mean values of the quantitative variables across the FV quartiles were then compared using the ANOVA test. Further, the ANCOVA test

Table 1 Characteristic of study participants according to quartiles of total vegetables and fruits intake

\begin{tabular}{|c|c|c|c|c|c|}
\hline & \multicolumn{5}{|c|}{ Quartiles of total vegetables and fruits intake } \\
\hline & $\begin{array}{l}1 \\
(n=100)\end{array}$ & $\begin{array}{l}2 \\
(n=100)\end{array}$ & $\begin{array}{l}3 \\
(n=100)\end{array}$ & $\begin{array}{l}4 \\
(n=100)\end{array}$ & $p$-trend ${ }^{\mathrm{a}}$ \\
\hline g/day (median) & 233.9 & 332.1 & 378.3 & 451.6 & \\
\hline Age (years) & $33.3 \pm 7$ & $34.0 \pm 7.7$ & $34.2 \pm 7.5$ & $34.1 \pm 7.1$ & 0.4 \\
\hline Education (years) & $12.1 \pm 3.4$ & $12.8 \pm 3.1$ & $12.5 \pm 3.1$ & $12.4 \pm 3.8$ & 0.6 \\
\hline BMI $\left(\mathrm{kg} / \mathrm{m}^{2}\right)$ & $25.7 \pm 3$ & $26.2 \pm 3.36$ & $26.3 \pm 2.6$ & $25.5 \pm 3$ & 0.7 \\
\hline Physical activity (MET/h/week) & $487.4 \pm 275.6$ & $473.1 \pm 292.5$ & $546.7 \pm 247.9$ & $500.7 \pm 340.5$ & 0.3 \\
\hline Height (cm) & $161.6 \pm 4.7$ & $161.5 \pm 4.7$ & $161.8 \pm 4.1$ & $161.9 \pm 4.7$ & 0.5 \\
\hline Weight (kg) & $66.8 \pm 7.9$ & $67.9 \pm 9.6$ & $68.8 \pm 7.3$ & $66.4 \pm 7.7$ & 0.9 \\
\hline Family size (n) & $4.3 \pm 1.3$ & $4.5 \pm 1.1$ & $4.4 \pm 1.3$ & $4.4 \pm 1.4$ & 0.7 \\
\hline Dietary supplement use (\%) & $45(45 \%)$ & $49(49 \%)$ & $47(47 \%)$ & $53(53 \%)$ & $0.5^{b}$ \\
\hline Energy intake (kcal) & $1579.6 \pm 288.5^{c}$ & $1614.5 \pm 266$ & $1629.4 \pm 289.6$ & $1752.1 \pm 355.6$ & $<0.001$ \\
\hline Protein intake (g) & $56 \pm 9.5^{c}$ & $58.7 \pm 10.1$ & $59.5 \pm 9.7$ & $64.8 \pm 11.5$ & $<0.001$ \\
\hline Carbohydrate intake (g) & $218.5 \pm 47.1^{c}$ & $237 \pm 44.5$ & $240.1 \pm 48.6$ & $261 \pm 57.4$ & $<0.001$ \\
\hline Fat intake (g) & $52.8 \pm 13.7^{c}$ & $48 \pm 11.3$ & $48 \pm 13.1$ & $50.8 \pm 15.2$ & $0.003^{d}$ \\
\hline Energy of protein (\%) & $14.2 \pm 1.2$ & $14.6 \pm 1.4$ & $14.6 \pm 1.3$ & $14.8 \pm 1.4$ & 0.001 \\
\hline Energy of carbohydrate (\%) & $55.6 \pm 5.3$ & $58.9 \pm 4.3$ & $59.2 \pm 5.2$ & $59.7 \pm 4.4$ & $<0.001^{d}$ \\
\hline Energy of fat (\%) & $30.6 \pm 5.7$ & $27.1 \pm 4.6$ & $27 \pm 5.2$ & $26.4 \pm 4.5$ & $<0.001^{d}$ \\
\hline Total fiber intake (g) & $38.9 \pm 18.2^{c}$ & $42.8 \pm 14.4$ & $40.5 \pm 16.8$ & $46.8 \pm 18.7$ & $<0.001^{d}$ \\
\hline Healthy eating index score & $46.6 \pm 5.3^{e}$ & $47 \pm 4.8$ & $48.3 \pm 6.1$ & $50.4 \pm 7.6$ & $<0.001^{d}$ \\
\hline
\end{tabular}

Values are means (standard deviations) or percentages unless stated otherwise

Vegetables include white cabbage, red cabbage, broccoli, cauliflower, spinach, lettuce, vegetable greens, carrot, yellow squash, cucumber, tomato, green squash, eggplant, celery, green peas, green beans, garlic, onion, bell peppers, turnip, mushroom, green peppers, olive, corn, leek and artichoke

Fruits include strawberry, blackberry, mulberry, orange, tangerine, sweet lemon, sour lemon, dried berries, grapefruit, cantaloupe, melon, pears, apricot, cherry, apple, plum, peach, persimmon, nectarine, greengage, figs, kiwi fruit, pomegranate, date, plum, sour cherry, banana, apple juice, cantaloupe juice, grapes, raisin, dry peach and apricot, fruit juice

a ANOVA

b Chi-square test

c Geometric mean \pm SEM

d Kruskal-Wallis test

e Median \pm interquartile range 
was utilized to compare the mean FV intake in the two groups after adjusting for potential confounders including BMI, energy intake, and HEI score. Variables with $p$ value $<0.05$ in ANOVA test were selected for adjustment. In addition, based on evidence from the literature, we selected age and physical activity as potential confounders [37]. Total vegetables and total fruits intake were mutually adjusted. For all of the vegetables and fruits sub-groups, FV intake was adjusted.

The relationship between FV intake and odds of depression was analyzed by simple logistic regression. In addition to the unadjusted analysis (Model 1), we used multivariable models to assess the relationship between FV intake and depression (Model 2). In Model 2, we adjusted for age, BMI, physical activity, energy intake, and HEI. Total vegetables and total fruits intake were mutually adjusted. For all of the vegetables and fruits subgroups, other subgroups of FV intake were also adjusted. Tests for trend were performed by introducing the categorical variables as continuous parameters in the models. $p$ values less than 0.05 were considered significant.

\section{Results}

The prevalence of mild, moderate, severe, and very severe depression was $10 \%, 8.5 \%, 5.8 \%$, and $1 \%$, respectively. The characteristics of the participants according to the quartiles of intake of total vegetables and fruits are presented in Tables 1, 2, and 3. With elevation of the total FV (Table 1), total vegetables (Table 2) and total fruits (Table 3) quartiles, the subjects had higher intake of energy, protein, carbohydrate, total fiber, percentage of energy from carbohydrate $(p$ trend $<0.04)$, and lower intake of fat and percentage of energy from fat ( $p$ trend $<0.005$ ). Upon increasing the total FV and total vegetables, the subjects had a higher percentage of energy from protein $(p$-trend $<0.002)$. In addition, with an elevation of the total FV and total fruits quartiles, the subjects had a higher HEI score $(p$-trend $<0.001)$.

Table 2 Characteristic of study participants according to quartiles of total vegetables intake

\begin{tabular}{|c|c|c|c|c|c|}
\hline & \multicolumn{5}{|c|}{ Quartiles of total vegetables intake } \\
\hline & $\begin{array}{l}1 \\
(n=100)\end{array}$ & $\begin{array}{l}2 \\
(n=100)\end{array}$ & $\begin{array}{l}3 \\
(n=100)\end{array}$ & $\begin{array}{l}4 \\
(n=100)\end{array}$ & $p$-trend $^{\text {a }}$ \\
\hline g/day (median) & 119.6 & 170.6 & 200.6 & 251.7 & \\
\hline Age (years) & $34.3 \pm 7.5$ & $32.7 \pm 7.1$ & $34.3 \pm 7.4$ & $34.3 \pm 7.1$ & 0.5 \\
\hline Education (years) & $12 \pm 3.6$ & $13 \pm 3$ & $12.7 \pm 3.4$ & $12.2 \pm 3.4$ & 0.8 \\
\hline $\mathrm{BMI}\left(\mathrm{kg} / \mathrm{m}^{2}\right)$ & $25.9 \pm 3.2$ & $25.6 \pm 2.6$ & $25.9 \pm 3.1$ & $26.4 \pm 3.1$ & 0.1 \\
\hline Physical activity (MET/h/week) & $497 \pm 292.4$ & $510 \pm 273.2$ & $473 \pm 256.8$ & $527.8 \pm 338.1$ & 0.6 \\
\hline Height (cm) & $161.4 \pm 4.7$ & $161.7 \pm 4.9$ & $162 \pm 4.3$ & $161.8 \pm 4.4$ & 0.4 \\
\hline Weight (kg) & $66.7 \pm 7.4$ & $66.9 \pm 8$ & $68 \pm 9$ & $68.3 \pm 8.5$ & 0.1 \\
\hline Family size (n) & $4.5 \pm 1.2$ & $4.3 \pm 1.3$ & $4.4 \pm 1.3$ & $4.4 \pm 1.2$ & 0.8 \\
\hline Dietary supplement use (\%) & $50(50 \%)$ & $46(46 \%)$ & $57(57 \%)$ & $41(41 \%)$ & $0.5^{\mathrm{b}}$ \\
\hline Energy intake (kcal) & $1600.3 \pm 276.5^{c}$ & $1606.6 \pm 289.7$ & $1632.7 \pm 274.5$ & $1734.4 \pm 366.0$ & 0.001 \\
\hline Protein intake (g) & $56.9 \pm 9.1^{c}$ & $58.0 \pm 10.5$ & $59.6 \pm 8.9$ & $64.5 \pm 12.2$ & $<0.001$ \\
\hline Carbohydrate intake (g) & $224.6 \pm 50.7^{c}$ & $238.4 \pm 47.1$ & $240.6 \pm 50.1$ & $251.9 \pm 56.1$ & $<0.001$ \\
\hline Fat intake (g) & $51.7 \pm 13.3^{c}$ & $47.0 \pm 11.5$ & $48.4 \pm 11.4$ & $52.7 \pm 16.5$ & $0.004^{d}$ \\
\hline Energy of protein (\%) & $14.2 \pm 1.4$ & $14.5 \pm 1.2$ & $14.6 \pm 1.2$ & $14.9 \pm 1.4$ & $<0.001$ \\
\hline Energy of carbohydrate (\%) & $56.4 \pm 6$ & $59.5 \pm 4.2$ & $59.1 \pm 4.7$ & $58.3 \pm 4.7$ & $<0.001^{d}$ \\
\hline Energy of fat (\%) & $29.7 \pm 6.1$ & $26.6 \pm 4.3$ & $27.1 \pm 5$ & $27.7 \pm 5$ & $<0.001^{d}$ \\
\hline Total fiber intake (g) & $40.8 \pm 18.4^{c}$ & $42.3 \pm 16.8$ & $40.9 \pm 17.0$ & $44.7 \pm 16.9$ & $0.034^{d}$ \\
\hline Healthy eating index score & $46.9 \pm 5.6^{e}$ & $48.7 \pm 6.6$ & $47.6 \pm 4.5$ & $49 \pm 7.5$ & $0.06^{d}$ \\
\hline
\end{tabular}

Values are means (standard deviations) or percentages unless stated otherwise

Total vegetables are defined as in Table 1

a ANOVA

b Chi-square test

c Geometric mean \pm SEM

d Kruskal-wallis test

e Median \pm interquartile range 
Table 3 Characteristic of study participants according to quartiles of total fruits intake

\begin{tabular}{|c|c|c|c|c|c|}
\hline & \multicolumn{5}{|c|}{ Quartiles of total fruits intake } \\
\hline & $\begin{array}{l}1 \\
(n=100)\end{array}$ & $\begin{array}{l}2 \\
(n=100)\end{array}$ & $\begin{array}{l}3 \\
(n=100)\end{array}$ & $\begin{array}{l}4 \\
(n=100)\end{array}$ & $p$-trend ${ }^{b}$ \\
\hline g/day (median) & 103.7 & 177.8 & 229.6 & 229.6 & \\
\hline Age (years) & $34 \pm 7.3$ & $33.4 \pm 7.7$ & $34.8 \pm 6.8$ & $33.4 \pm 7.3$ & 0.8 \\
\hline Education (years) & $12.1 \pm 3.5$ & $12.8 \pm 3.1$ & $12.2 \pm 3.3$ & $12.7 \pm 3.6$ & 0.3 \\
\hline $\mathrm{BMI}\left(\mathrm{kg} / \mathrm{m}^{2}\right)$ & $26.3 \pm 3$ & $25.8 \pm 3.1$ & $26 \pm 2.7$ & $25.6 \pm 3.1$ & 0.1 \\
\hline Physical activity (MET/h/week) & $474.7 \pm 287.9$ & $495.5 \pm 235.7$ & $515.9 \pm 282.7$ & $521.8 \pm 349.6$ & 0.2 \\
\hline Height (cm) & $161.8 \pm 4.6$ & $162.1 \pm 4.4$ & $161 \pm 4.3$ & $161.9 \pm 4.9$ & 0.6 \\
\hline Weight (kg) & $68.5 \pm 8.8$ & $67.6 \pm 9$ & $67.1 \pm 6.9$ & $66.7 \pm 8.1$ & 0.1 \\
\hline Family size (n) & $4.3 \pm 1.3$ & $4.3 \pm 1.2$ & $4.6 \pm 1.1$ & $1.4 \pm 4.3$ & 0.7 \\
\hline Dietary supplement use (\%) & $37(37 \%)$ & $56(56 \%)$ & $42(42 \%)$ & $59(59 \%)$ & $0.5^{c}$ \\
\hline Energy intake (kcal) & $1603 \pm 273.3^{d}$ & $1561.3 \pm 254.6$ & $1689.6 \pm 350.8$ & $1721.8 \pm 319.2$ & 0.001 \\
\hline Protein intake (g) & $57.0 \pm 9.9^{d}$ & $57.0 \pm 9.6$ & $62.2 \pm 11.5$ & $62.8 \pm 10.3$ & 0.001 \\
\hline Carbohydrate intake (g) & $218.2 \pm 45.3^{d}$ & $227.9 \pm 42.9$ & $250.7 \pm 51.2$ & $260.3 \pm 55.6$ & 0.001 \\
\hline Fat intake (g) & $56.8 \pm 12.6^{d}$ & $48.2 \pm 10.5$ & $50.9 \pm 16.4$ & $49.6 \pm 12.6$ & $<0.001^{e}$ \\
\hline Energy of protein (\%) & $14.3 \pm 1.4$ & $14.6 \pm 1.3$ & $14.7 \pm 1.1$ & $14.6 \pm 1.4$ & 0.051 \\
\hline Energy of carbohydrate (\%) & $54.7 \pm 5$ & $58.5 \pm 4.2$ & $59.5 \pm 4.5$ & $60.6 \pm 4.5$ & $<0.001^{e}$ \\
\hline Energy of fat (\%) & $31.6 \pm 5.6$ & $27.5 \pm 4.5$ & $26.4 \pm 4.5$ & $25.6 \pm 4.4$ & $<0.001^{\mathrm{e}}$ \\
\hline Total fiber intake (g) & $42.7 \pm 16.4^{d}$ & $43.5 \pm 15.7$ & $45.6 \pm 16.3$ & $50.6 \pm 19.6$ & $<0.001^{\mathrm{e}}$ \\
\hline Healthy eating index score & $47.1 \pm 5.3^{f}$ & $46.6 \pm 4.7$ & $47.4 \pm 6.9$ & $50.4 \pm 6.0$ & $<0.001^{e}$ \\
\hline
\end{tabular}

Values are means (standard deviations) or percentages unless stated otherwise

Total fruits were defined as in Table 1

a ANOVA

${ }^{b}$ Chi square test

c Geometric mean \pm SEM

d Kruskal-Wallis test

e Median \pm interquartile range

The comparison of FV intake between depressed and healthy subjects is presented in Table 4 . The intake of total FV and all of their subgroups were significantly lower in depressed subjects as compared to their healthy counterparts $(p<0.02)$. After adjustment for confounding variables, these differences remained significant for total $\mathrm{FV}$, total vegetables, cruciferous vegetables, other vegetables, total fruits, citrus fruits, and other fruits $(p<0.02)$.

The odds ratio (OR) of depression across quartiles of FV intake, before and after adjustment for confounding factors, is presented in two different models in Table 5 . Before adjusting the confounders, the subjects in the lowest quartile of total FV intake and its all subgroups had a higher OR of depression compared with those in the highest quartile ( $p$ trend $<0.04)$. After adjusting for confounders, the participants in the lowest quartile of total FV, total vegetables, total fruits, citrus, other fruits and green leafy vegetables had a higher OR of depression compared with those in the highest quartile
( $p$-trend $<0.03$ ). Finally, the participants in the first quartile of berries $(p=0.01)$ had a higher OR compared with those in the highest quartile. However, no dose-response relationship was observed.

\section{Discussion}

This study examined the relationship between the intake of various FV and depression among apparently healthy women. The results of this study suggested that a high intake of total FV, total vegetables, total fruits, citrus, other fruits and green leafy vegetables was independently related to a lower OR of depression. In addition, berries were inversely associated with depression, although no clear dose-response relationship was found.

Studies conducted to investigate the relationship between specific subgroups of FV and depression are very limited and there is no study in healthy adult populations. Our study provided evidence supporting benefits 
Table 4 Fruits and vegetables intake across depressed and healthy subjects

\begin{tabular}{|c|c|c|c|c|c|}
\hline Daily intake (g) & $\begin{array}{l}\text { Depressed } \\
(n=101) \\
\text { Mean } \pm \text { SD }\end{array}$ & $\begin{array}{l}\text { Healthy } \\
(n=299) \\
\text { Mean } \pm \text { SD }\end{array}$ & $p^{a}$ & $p^{\mathbf{b}}$ & $p^{c}$ \\
\hline Total vegetables and fruits & $289.1 \pm 104.7$ & $373.2 \pm 76.4$ & $<0.001$ & $<0.001$ & $<0.001$ \\
\hline Total vegetables & $160.2 \pm 69.1$ & $197.1 \pm 54.9$ & $<0.001^{d}$ & $<0.001$ & $<0.001$ \\
\hline Cruciferous vegetables & $4.0 \pm 5.0$ & $6.5 \pm 6.5$ & $<0.001^{d}$ & $<0.001$ & 0.005 \\
\hline Green leafy vegetables & $16.3 \pm 13.9^{e}$ & $23.9 \pm 12.6$ & $<0.001$ & $<0.001$ & 0.06 \\
\hline Dark yellow vegetables & $5.1 \pm 4.1$ & $6.2 \pm 4.5$ & 0.01 & 0.011 & 0.1 \\
\hline Other vegetables & $130.6 \pm 55.2$ & $157.9 \pm 45.4$ & $<0.001^{d}$ & $<0.001$ & 0.016 \\
\hline Total fruits & $118.5 \pm 53.7^{\mathrm{e}}$ & $170.6 \pm 48.6$ & $<0.001$ & $<0.001$ & $<0.001$ \\
\hline Berries fruits & $0.5 \pm 0.5$ & $0.8 \pm 0.6$ & $<0.001^{d}$ & $<0.001$ & 0.1 \\
\hline Citrus fruits & $25.3 \pm 12.5$ & $35.2 \pm 10.9$ & $<0.001^{d}$ & $<0.001$ & $<0.001$ \\
\hline Other fruits & $93.8 \pm 45.9^{e}$ & $134.4 \pm 44.5$ & $<0.001$ & $<0.001$ & $<0.001$ \\
\hline
\end{tabular}

Total vegetables and fruits are defined as in Table 1

Cruciferous vegetables include white cabbage, red cabbage, broccoli, cauliflower

Green leafy vegetables include spinach, lettuce, and green vegetables such as basil, parsley, cress, leek, spearmint, origany, coriander and scallion

Dark yellow vegetables include carrot, yellow squash

Other vegetables include cucumber, tomato, zucchini, eggplant, celery, green pea, green bean, garlic, onion, green pepper, bell peppers, turnip, mushroom, olive, corn and artichoke

Berries fruits include strawberry, white mulberry black mulberry and dried berries

Citrus fruits include orange, tangerine, grapefruits, sweet lemon, sour lemon, orange juice

Other fruits include cantaloupe, melon, pear, apricot, cherry, apple, peach, nectarine, greengage, fig, kiwi fruit, persimmon, pomegranate, date, plum, sour cherry, banana, pineapple, grapes, dry peach and apricot, raisin and fruit juice

Values are means (standard deviations)

a Unadjusted, Student $t$ test

b Adjusted for energy intake; ANCOVA test

c Adjusted for age, body mass index, physical activity, energy intake and healthy eating index score. Total vegetables and total fruits intake were mutually adjusted. For each vegetables and fruits sub-groups, total fruits and vegetables intake was adjusted; ANCOVA test

d Mann-Withney test

e Geometric mean \pm SEM

of consuming citrus, other fruits, green leafy vegetables and to a lesser extent berries.

Our findings are consistent with the results of other studies, suggesting an inverse relationship between FV consumption and depression. Cross-sectional studies $[3-5,7]$ and some prospective cohort studies $[8,9]$ have suggested that lower FV consumption was associated with a higher risk of depression. In addition, the inverse relationship between depression and fruits $[9,17,18$, $38]$ or vegetables $[9,15,39,40]$ consumptions has been separately indicated. A meta-analysis study indicated that intakes of both fruits and vegetables were inversely related to the risk of depression [10]. In subgroup analysis by the study design, higher fruits intake was associated to lower risk of depression in both cross-sectional and cohort studies. However, the association between higher vegetable intake and lower risk of depression was found in only cohort studies [11]. Contrary to these studies, the association between depression and FV intake or fruits and vegetables individually was not shown in other studies [3, 12-15, 17, 18, 32, 41, 42].
In some cross-sectional studies in elderly subjects, there was an association between high consumption of green leafy vegetables [16] as well as tomato and tomato products [25] and lower odds of depression. A casecontrol study which compared consumptions of food groups between depressed and healthy women revealed that subjects with more intake of citrus, berries, melons, other fruits, green leafy vegetables, yellow vegetables, and other vegetables had a lower chance of developing depression [43]. Since these are findings from a casecontrol study, the possibility that depression may influence the FV intake of subjects cannot be ruled out. In addition, other dietary components have not been controlled either.

Relevant data from clinical trials are scarce. Dietary improvements including increasing fruits and vegetables intake in patients with depression reduced the symptoms of depression [44]. However, in some other studies, higher intake of FV [45], concord grape juice [46] and blueberry juice [45] supplementation did not improve depression. 
Table 5 Odds ratio $(95 \% \mathrm{Cl})$ of depression according to quartiles $(\mathrm{Q})$ of fruits and vegetables intake

\begin{tabular}{|c|c|c|c|c|c|}
\hline Daily intake & Q1 & Q2 & Q3 & Q4 & $p$-trend \\
\hline $\begin{array}{l}\text { Total vegetables and fruits } \\
\mathrm{g} / \text { day (median) }\end{array}$ & 233.9 & 332.1 & 378.3 & 451.6 & \\
\hline Cases of depressed & 55 & 19 & 17 & 10 & \\
\hline $\begin{array}{l}\text { Model } 1 \\
p\end{array}$ & $\begin{array}{l}11(5.12-23.59) \\
<0.001\end{array}$ & $\begin{array}{l}2.1(0.92-4.8) \\
0.07\end{array}$ & $\begin{array}{l}1.84(0.79-4.25) \\
0.1\end{array}$ & 1 & $<0.001$ \\
\hline $\begin{array}{l}\text { Model } 2 \\
p\end{array}$ & $\begin{array}{l}18.83(7.96-44.51) \\
<0.001\end{array}$ & $\begin{array}{l}2.98(1.23-7.2) \\
0.01\end{array}$ & $\begin{array}{l}2.47(1.02-5.96) \\
0.04\end{array}$ & 1 & $<0.001$ \\
\hline $\begin{array}{l}\text { Total vegetables } \\
\text { g/day (median) }\end{array}$ & 125.4 & 176.6 & 203.2 & 245.8 & \\
\hline Cases of depressed & 54 & 16 & 14 & 17 & \\
\hline $\begin{array}{l}\text { Model } 1 \\
p\end{array}$ & $\begin{array}{l}5.73(2.98-11.01) \\
<0.001\end{array}$ & $\begin{array}{l}0.93(0.44-1.96) \\
0.8\end{array}$ & $\begin{array}{l}0.79(0.36-1.71) \\
0.5\end{array}$ & 1 & $<0.001$ \\
\hline $\begin{array}{l}\text { Model } 2 \\
p\end{array}$ & $\begin{array}{l}4.43(2.06-9.51) \\
<0.001\end{array}$ & $\begin{array}{l}1.14(0.50-2.59) \\
0.7\end{array}$ & $\begin{array}{l}1.07(0.46-2.5) \\
0.8\end{array}$ & 1 & 0.001 \\
\hline $\begin{array}{l}\text { Cruciferous vegetables } \\
\text { g/day (median) }\end{array}$ & 2.5 & 3.1 & 6.2 & 6.2 & \\
\hline Cases of depressed & 44 & 24 & 22 & 11 & \\
\hline $\begin{array}{l}\text { Model } 1 \\
p\end{array}$ & $\begin{array}{l}4.92(2.33-10.42) \\
<0.001\end{array}$ & $\begin{array}{l}1.79(0.82-3.91) \\
0.1\end{array}$ & $\begin{array}{l}1.53(0.69-3.37) \\
0.2\end{array}$ & 1 & 0.001 \\
\hline $\begin{array}{l}\text { Model } 2 \\
p\end{array}$ & $\begin{array}{l}1.6(0.57-4.48) \\
0.3\end{array}$ & $\begin{array}{l}0.94(0.34-2.55) \\
0.9\end{array}$ & $\begin{array}{l}1.29(0.52-3.21) \\
0.5\end{array}$ & 1 & 0.6 \\
\hline $\begin{array}{l}\text { Green leafy vegetables } \\
\text { g/day (median) }\end{array}$ & 14.3 & 21.6 & 24.8 & 31.6 & \\
\hline Cases of depressed & 49 & 17 & 15 & 20 & \\
\hline $\begin{array}{l}\text { Model } 1 \\
p\end{array}$ & $\begin{array}{l}3.84(2.05-7.19) \\
<0.001\end{array}$ & $\begin{array}{l}0.81(0.4-1.67) \\
0.5\end{array}$ & $\begin{array}{l}0.7(0.33-1.47) \\
0.3\end{array}$ & 1 & $<0.001$ \\
\hline $\begin{array}{l}\text { Model } 2 \\
p\end{array}$ & $\begin{array}{l}1.61(0.64-4.02) \\
0.3\end{array}$ & $\begin{array}{l}0.55(0.22-1.35) \\
0.1\end{array}$ & $\begin{array}{l}0.58(0.24-1.4) \\
0.2\end{array}$ & 1 & 0.02 \\
\hline $\begin{array}{l}\text { Dark yellow vegetables } \\
\text { g/day (median) }\end{array}$ & 2.1 & 4.3 & 5.7 & 7.7 & \\
\hline Cases of depressed & 34 & 25 & 20 & 22 & \\
\hline $\begin{array}{l}\text { Model } 1 \\
p\end{array}$ & $\begin{array}{l}1.82(0.97-3.42) \\
0.06\end{array}$ & $\begin{array}{l}1.18(0.61-2.27) \\
0.6\end{array}$ & $\begin{array}{l}0.88(0.44-1.57) \\
0.7\end{array}$ & 1 & 0.03 \\
\hline $\begin{array}{l}\text { Model } 2 \\
P\end{array}$ & $\begin{array}{l}0.45(0.18-1.09) \\
0.07\end{array}$ & $\begin{array}{l}0.61(0.26-1.41) \\
0.2\end{array}$ & $\begin{array}{l}0.68(0.3-1.53) \\
0.3\end{array}$ & 1 & 0.2 \\
\hline $\begin{array}{l}\text { Other vegetables } \\
\text { g/day (median) }\end{array}$ & 102.7 & 144.6 & 166.2 & 190.3 & \\
\hline Cases of depressed & 49 & 24 & 9 & 19 & \\
\hline $\begin{array}{l}\text { Model } 1 \\
p\end{array}$ & $\begin{array}{l}4.09(2.17-7.73) \\
<0.001\end{array}$ & $\begin{array}{l}1.34(0.68-2.65) \\
0.3\end{array}$ & $\begin{array}{l}0.42(0.18-0.98) \\
0.04\end{array}$ & 1 & $<0.001$ \\
\hline $\begin{array}{l}\text { Model } 2 \\
p\end{array}$ & $\begin{array}{l}2.05(0.88-4.79) \\
0.09\end{array}$ & $\begin{array}{l}1.43(0.64-3.23) \\
0.3\end{array}$ & $\begin{array}{l}0.5(0.19-1.33) \\
0.1\end{array}$ & 1 & 0.07 \\
\hline $\begin{array}{l}\text { Total fruits } \\
\text { g/day (median) }\end{array}$ & 108.3 & 155.6 & 180 & 209.2 & \\
\hline Cases of depressed & 58 & 17 & 14 & 12 & \\
\hline $\begin{array}{l}\text { Model } 1 \\
p\end{array}$ & $\begin{array}{l}10.12(4.91-20.85) \\
<0.001\end{array}$ & $\begin{array}{l}1.5(0.67-3.33) \\
0.3\end{array}$ & $\begin{array}{l}1.19(0.52-2.72) \\
0.6\end{array}$ & 1 & $<0.001$ \\
\hline $\begin{array}{l}\text { Model } 2 \\
p\end{array}$ & $\begin{array}{l}11.08(4.96-24.75) \\
<0.001\end{array}$ & $\begin{array}{l}2.12(0.90-5.01) \\
0.08\end{array}$ & $\begin{array}{l}1.27(0.54-2.99) \\
0.5\end{array}$ & 1 & $<0.001$ \\
\hline $\begin{array}{l}\text { Berries fruits } \\
\text { g/day (median) }\end{array}$ & 0.4 & 0.5 & 0.5 & 0.6 & \\
\hline Cases of depressed & 53 & 20 & 12 & 16 & \\
\hline $\begin{array}{l}\text { Model } 1 \\
p\end{array}$ & $\begin{array}{l}5.72(2.95-11.11) \\
<0.001\end{array}$ & $\begin{array}{l}1.33(0.64-2.75) \\
0.4\end{array}$ & $\begin{array}{l}0.69(0.30-1.54) \\
0.3\end{array}$ & 1 & 0.001 \\
\hline $\begin{array}{l}\text { Model } 2 \\
p\end{array}$ & $\begin{array}{l}2.77(1.24-6.18) \\
0.01\end{array}$ & $\begin{array}{l}0.81(0.34-1.91) \\
0.6\end{array}$ & $\begin{array}{l}0.68(0.27-1.68) \\
0.4\end{array}$ & 1 & 0.3 \\
\hline
\end{tabular}


Table 5 (continued)

\begin{tabular}{|c|c|c|c|c|c|}
\hline Daily intake & Q1 & Q2 & Q3 & Q4 & $p$-trend* \\
\hline $\begin{array}{l}\text { Citrus fruits } \\
\text { g/day (median) }\end{array}$ & 24.7 & 34.3 & 36.4 & 37.6 & \\
\hline Cases of depressed & 55 & 22 & 12 & 12 & \\
\hline $\begin{array}{l}\text { Model } 1 \\
p\end{array}$ & $\begin{array}{l}8.96(4.36-18.42) \\
<0.001\end{array}$ & $\begin{array}{l}2.06(0.96-4.45) \\
0.06\end{array}$ & $\begin{array}{l}1(0.42-2.34) \\
1\end{array}$ & 1 & $<0.001$ \\
\hline $\begin{array}{l}\text { Model } 2 \\
p\end{array}$ & $\begin{array}{l}3.14(1.34-7.38) \\
0.008\end{array}$ & $\begin{array}{l}1.27(0.53-3.04) \\
0.5\end{array}$ & $\begin{array}{l}0.68(0.27-1.74) \\
0.4\end{array}$ & 1 & 0.004 \\
\hline $\begin{array}{l}\text { Other fruits } \\
\text { g/day (median) }\end{array}$ & 85.1 & 121.1 & 141 & 167.4 & \\
\hline Cases of depressed & 55 & 19 & 14 & 13 & \\
\hline $\begin{array}{l}\text { Model } 1 \\
p\end{array}$ & $\begin{array}{l}8.17(4.04-16.52) \\
<0.001\end{array}$ & $\begin{array}{l}1.57(0.72-3.38) \\
0.2\end{array}$ & $\begin{array}{l}1.08(0.48-2.45) \\
0.8\end{array}$ & 1 & $<0.001$ \\
\hline $\begin{array}{l}\text { Model } 2 \\
p\end{array}$ & $\begin{array}{l}4.93(1.97-12.31) \\
0.001\end{array}$ & $\begin{array}{l}1.61(0.67-3.89) \\
0.2\end{array}$ & $\begin{array}{l}1.03(0.43-2.51) \\
0.9\end{array}$ & 1 & $<0.001$ \\
\hline
\end{tabular}

Model 1: unadjusted

Model 2: adjusted for age, body mass index, physical activity, energy intake and healthy eating index. Total vegetables and total fruits intake were mutually adjusted. For each vegetables and fruits sub-groups, other sub-groups of fruits and vegetables intake was adjusted

Fruits and vegetables are defined as in Tables 1 and 4

* Tests for trend were performed by entering the categorical variables as continuous parameters in the models

The biological mechanisms for the inverse association of FV intake and depression are not clear.

However, this association may be due to the large amount of bioactive compounds present in FV [24]. FV have a high content of micronutrients and phytochemicals including antioxidants and anti-inflammatory components which have detrimental effects on depression [17]. Antioxidants such as carotenoids, vitamin $C$, and vitamin E might prevent depressive symptoms [42]. High intake of B vitamins such as folic acid have been associated with lower risk of depression [47]. FV also supplies dietary fiber whose role in improving mood has been suggested [48]. Green leafy vegetables are good sources of folate and magnesium which are important in the prevention of depression. Folate is involved in the metabolism of monoamines such as serotonin in the brain [42]. Reduced synthesis of serotonin results to depressed mood [49]. In magnesium deficiency, high levels of calcium and glutamate reduce synaptic function and lead to depression [50]. In addition, lower levels of C-reactive protein, a marker of low-grade inflammation, has been reported in magnesium sufficiency [22]. In a study on rats, it was found that tomato juice inhibited monoamine oxidase (MAO) enzyme. This result suggested the anti-depressant properties of tomato [51]. In addition, Aronia melanocarpa berry juice with the highest polyphenol contents among fruits could yield an antidepressant effect in rats [52]. A study found that heptamethoxy flavone (HMF), a citrus flavonoid, increases the expression of BDNF in the hippocampus in rats, thereby exerting anti-depressant effects [53].
Women who were included in the present study were not informed of their depression status, which is one of the strengths of this study. When subjects are aware of their depression disorder, they might change their food intake. Another strength of our study was the adjustment for many confounding variables, especially the overall quality of diet. However, this study was limited in some aspects. First, there is a probability of error in answering FFQ questions. The reliability and validity of the utilized FFQ were not assessed for this population. Second, although we adjusted for many confounding variables, there may still be residual confounding variables which would affect our results. In addition, as with all cross-sectional studies, the present study reveals the existence or the absence of a relationship, while it does not specify causality. Further, FV-rich diets have been accompanied by a healthy lifestyle which may have not been adjusted in our analysis. Finally, our findings may not be generalized to other populations.

\section{Conclusions}

In conclusion, we found that higher consumption of total $\mathrm{FV}$, total vegetables, total fruits, citrus, other fruits, green leafy vegetables and berries might be associated with a lower OR of depression. The findings from this study support encouragement of FV consumption as part of a healthy diet and highlight the importance of FV consumption and a number of their subgroups in mitigating the chance of depression. Further studies focusing specifically on FV subgroups are required to confirm these findings. 


\begin{abstract}
Abbreviations
FV: fruits and vegetables; BDNF: brain-derived neurotrophic factor; BMI: body mass index; DASS: Depression Anxiety Stress Scale; FFQ: food frequency questionnaire; WHO: World Health Organization; IPAQ: international physical activity questionnaire; HEl: healthy eating index; OR: odds ratio; MAO: monoamine oxidase; HMF: heptamethoxy flavone.
\end{abstract}

\section{Authors' contributions}

The authors' contributions are as follows: FS and GS conceived and developed the idea for the paper and revised the manuscript; EB contributed to data collection and wrote numerous drafts; MQ, FK and NP contributed to data analysis and interpretation of the data. All authors read and approved the final manuscript.

\section{Author details}

1 Department of Community Nutrition, School of Nutritional Sciences and Dietetics, Tehran University of Medical Sciences, Hojatdost Street, Naderi Street, KeshavarzBlv., Tehran, Iran. ${ }^{2}$ Non-communicable Diseases Research Center, Alborz University of Medical Sciences, Karaj, Iran. ${ }^{3}$ Department of Cellular, Molecular Nutrition, School of Nutritional Sciences and Dietetics, Tehran University of Medical Sciences, Tehran, Iran. ${ }^{4}$ Shariati Hospital, School of Medicine, Tehran University of Medical Sciences, Tehran, Iran. ${ }^{5}$ Children Hospital of Excellence, School of Medicine, Tehran University of Medical Sciences, Tehran, Iran

\section{Acknowledgements}

The authors thank the support of Lorestan University of Medical Sciences (LUMS).

\section{Competing interests}

The authors declare that they have no competing interests.

\section{Availability of data and materials}

The datasets used and/or analyzed during the current study are available from the corresponding author on reasonable request.

\section{Consent for publication}

Not applicable.

\section{Ethics approval and consent to participate}

The Ethics Committee of Tehran University of Medical Sciences approved the protocol of this study.

\section{Funding}

This research project was supported by Tehran University of Medical Sciences (TUMS) (Grant No. 96-450-18).

\section{Publisher's Note}

Springer Nature remains neutral with regard to jurisdictional claims in published maps and institutional affiliations.

Received: 31 May 2018 Accepted: 21 October 2018

Published online: 01 November 2018

\section{References}

1. WHO (The World Health Organization). Depression. http://www.who.int/ mediacentre/factsheets/fs369/en/. Accessed Jun 2017.

2. Noorbala AA, Faghihzadeh S, Kamali K, Bagheri Yazdi SA, Hajebi A, Mousavi MT, Akhondzadeh S, Faghihzadeh E, Nouri B. Mental Health Survey of the Iranian Adult Population in 2015. Arch Iran Med (AIM). 2017;20:3.

3. McMartin SE, Jacka FN, Colman I. The association between fruit and vegetable consumption and mental health disorders: evidence from five waves of a national survey of Canadians. Prev Med. 2013;56(3):225-30

4. Poorrezaeian M, Siassi F, Milajerdi A, Qorbani M, Karimi J, Sohrabi-Kabi $\mathrm{R}$, Pak N, Sotoudeh G. Depression is related to dietary diversity score in women: a cross-sectional study from a developing country. Ann Gen Psychiatry. 2017;16(1):39.
5. Payne ME, Steck SE, George RR, Steffens DC. Fruit, vegetable, and antioxidant intakes are lower in older adults with depression. J Acad Nutr Diet. 2012;112(12):2022-7.

6. Bishwajit G, O'Leary DP, Ghosh S, Sanni Y, Shangfeng T, Zhanchun F. Association between depression and fruit and vegetable consumption among adults in South Asia. BMC Psychiatry. 2017;17(1):15.

7. Saghafian F, Malmir H, Saneei P, Keshteli AH, Hosseinzadeh-Attar MJ, Afshar H, Siassi F, Esmaillzadeh A, Adibi P. Consumption of fruit and vegetables in relation with psychological disorders in Iranian adults. Eur J Nutr. 2018:57(6):2295-306.

8. Lai JS, Hure AJ, Oldmeadow C, McEvoy M, Byles J, Attia J. Prospective study on the association between diet quality and depression in midaged women over 9 years. Eur J Nutr. 2017;56(1):273-81.

9. Gangwisch JE, Hale L, Garcia L, Malaspina D, Opler MG, Payne ME, Rossom RC, Lane D. High glycemic index diet as a risk factor for depression: analyses from the Women's Health Initiative. Am J Clin Nutr. 2015. https:// doi.org/10.3945/ajen103846.

10. Liu X, Yan Y, Li F, Zhang D. Fruit and vegetable consumption and the risk of depression: a meta-analysis. Nutrition. 2016;32(3):296-302.

11. Fulkerson JA, Sherwood NE, Perry CL, Neumark-Sztainer D, Story M. Depressive symptoms and adolescent eating and health behaviors: a multifaceted view in a population-based sample. Prev Med. 2004;38(6):865-75.

12. Mistry R, McCarthy WJ, Yancey AK, Lu Y, Patel M. Resilience and patterns of health risk behaviors in California adolescents. Prev Med. 2009;48(3):291-7.

13. Meegan AP, Perry IJ, Phillips CM. The association between dietary quality and dietary guideline adherence with mental health outcomes in adults: a cross-sectional analysis. Nutrients. 2017;9(3):238.

14. Tsai AC, Chang T-L, Chi S-H. Frequent consumption of vegetables predicts lower risk of depression in older Taiwanese-results of a prospective population-based study. Public Health Nutr. 2012;15(6):1087-92.

15. Woo J, Lynn H, Lau W, Leung J, Lau E, Wong S, KwokT. Nutrient intake and psychological health in an elderly Chinese population. Int J Geriatr Psychiatry. 2006;21(11):1036-43.

16. Mamplekou E, Bountziouka V, Psaltopoulou T, Zeimbekis A, Tsakoundakis N, Papaerakleous N, Gotsis E, Metallinos G, Pounis G, Polychronopoulos E. Urban environment, physical inactivity and unhealthy dietary habits correlate to depression among elderly living in eastern Mediterranean islands: the MEDIS (MEDiterranean ISlands Elderly) study. J Nutr Health Aging. 2010;14(6):449-55.

17. Mihrshahi S, Dobson A, Mishra G. Fruit and vegetable consumption and prevalence and incidence of depressive symptoms in mid-age women: results from the Australian longitudinal study on women's health. Eur J Clin Nutr. 2015;69(5):585-91.

18. Sánchez-Villegas A, Delgado-Rodríguez M, Alonso A, Schlatter J, Lahortiga F, Majem LS, Martínez-González MA. Association of the Mediterranean dietary pattern with the incidence of depression: the Seguimiento Universidad de Navarra/University of Navarra follow-up (SUN) cohort. Arch Gen Psychiatry. 2009;66(10):1090-8.

19. Perez-Cornago A, Lopez-Legarrea P, de la Iglesia R, Lahortiga F, Martinez JA, Zulet MA. Longitudinal relationship of diet and oxidative stress with depressive symptoms in patients with metabolic syndrome after following a weight loss treatment: the RESMENA project. Clin Nutr. 2014;33(6):1061-7.

20. Black C, Penninx B, Bot M, Odegaard A, Gross M, Matthews K, Jacobs D. Oxidative stress, anti-oxidants and the cross-sectional and longitudinal association with depressive symptoms: results from the CARDIA study. Transl Psychiatry. 2016;6(2):e743.

21. Howren MB, Lamkin DM, Suls J. Associations of depression with C-reactive protein, IL-1, and IL-6: a meta-analysis. Psychosom Med. 2009;71(2):171-86.

22. Rooney C, McKinley MC, Woodside JV. The potential role of fruit and vegetables in aspects of psychological well-being: a review of the literature and future directions. Pro Nutr Soc. 2013;72(4):420-32.

23. Black CN, Bot M, Scheffer PG, Cuijpers P, Penninx BWJH. Is depression associated with increased oxidative stress? A systematic review and meta-analysis. Psychoneuroendocrinology. 2015;51:164-75. 
24. Muraki I, Imamura F, Manson JE, Hu FB, Willett WC, van Dam RM, Sun Q. Fruit consumption and risk of type 2 diabetes: results from three prospective longitudinal cohort studies. Br Med J. 2013;347:f5001.

25. Niu K, Guo H, Kakizaki M, Cui Y, Ohmori-Matsuda K, Guan L, Hozawa A, Kuriyama S, Tsuboya T, Ohrui T. A tomato-rich diet is related to depressive symptoms among an elderly population aged 70 years and over: a population-based, cross-sectional analysis. J Affect Disord. 2013;144(1):165-70.

26. Brookie KL, Best $\mathrm{Gl}$, Conner TS. Intake of raw fruits and vegetables is associated with better mental health than intake of processed fruits and vegetables. Front Psychol. 2018;9:487.

27. Afzali A, Delavar A, Borjali A, Mirzamani M. Psychometric properties of DASS-42 as assessed in a sample of Kermanshah High School students. J Res Behav Sci. 2007:5(2):81-92.

28. Lovibond S, Lovibond P. Manual for the Depression Anxiety Stress Scale. Sydney: Psychological Foundation of Australia; 1995.

29. UNSW. Depression Anxiety and Stress Scale (DASS). http://www.psy.unsw. edu.au/groups. Accessed Dec 2017.

30. Committee IR. Guidelines for data processing and analysis of the International Physical Activity Questionnaire (IPAQ)-short and long forms. Retrieved September 2005, 17: 2008.

31. Esfahani FH, Asghari G, Mirmiran P, Azizi F. Reproducibility and relative validity of food group intake in a food frequency questionnaire developed for the Tehran Lipid and Glucose Study. J Epidemiol. 2010;20(2):150-8.

32. National Nutrient Database for Standard Reference. United States Department of Agricultural. 2015. https://ndb.nal.usda.gov/ndb/. Accessed Dec 2017.

33. Sánchez-Villegas A, Verberne L, De Irala J, Ruíz-Canela M, Toledo E, Serra-Majem L, Martínez-González MA. Dietary fat intake and the risk of depression: the SUN Project. PLoS ONE. 2011;6(1):e16268.

34. Liu S, Manson JE, Lee IM, Cole SR, Hennekens CH, Willett WC, Buring JE. Fruit and vegetable intake and risk of cardiovascular disease: the Women's Health Study. Am J Clin Nutr. 2000;72(4):922-8.

35. Liu S, Serdula M, Janket S-J, Cook NR, Sesso HD, Willett WC, Manson JE, Buring JE. A prospective study of fruit and vegetable intake and the risk of type 2 diabetes in women. Diabetes Care. 2004;27(12):2993-6.

36. Overview \& Background of The Healthy Eating Index. National Cancer Institute. 2015. https://epi.grants.cancer.gov/hei/. Accessed Dec 2017.

37. Nooyens AC, Bueno-de-Mesquita HB, van Boxtel MP, van Gelder BM, Verhagen $\mathrm{H}$, Verschuren WM. Fruit and vegetable intake and cognitive decline in middle-aged men and women: the Doetinchem Cohort Study. Br J Nutr. 2011:106(5):752-61.

38. Liu C, Xie B, Chou C-P, Koprowski C, Zhou D, Palmer P, Sun P, Guo Q, Duan L, Sun X. Perceived stress, depression and food consumption frequency in the college students of China Seven Cities. Physiol Behav. 2007:92(4):748-54.

39. Shahar S, Hassan J, Sundar WV, Kong AYW, Chin SP, Ahmad SA, Lee LK. Determinants of depression and insomnia among institutionalized elderly people in Malaysia. Asian J Psychiatry. 2011;4(3):188-95.
40. Ribeiro SM, Malmstrom TK, Morley JE, Miller DK. Fruit and vegetable intake, physical activity, and depressive symptoms in the African American Health (AAH) study. J Affect Disord. 2017;220:31-7.

41. Hintikka J, Tolmunen T, Honkalampi K, Haatainen K, Koivumaa-Honkanen $H$, Tanskanen A, Viinamäki H. Daily tea drinking is associated with a low level of depressive symptoms in the Finnish general population. Eur J Epidemiol. 2005;20(4):359-63.

42. Chi SH, Wang JY, Tsai AC. Combined association of leisure-time physical activity and fruit and vegetable consumption with depressive symptoms in older Taiwanese: results of a national cohort study. Geriatr gerontol Int. 2016;16(2):244-51.

43. Kargarnovin Z, Pourghassem Gargari B, Ranjbar F, Rashidkhani B, Zareiy S, Hosein Poor S, Nasiri Z. The association of food groups with major depression in adult women resident in tabriz. Urmia Med J. 2014;24(11):872-82.

44. Jacka FN, O'Neil A, Opie R, Itsiopoulos C, Cotton S, Mohebbi M, Castle D, Dash S, Mihalopoulos C, Chatterton ML. A randomised controlled trial of dietary improvement for adults with major depression (the 'SMILES'trial). BMC Med. 2017:15(1):23.

45. Krikorian R, Shidler MD, Nash TA, Kalt W, Vinqvist-Tymchuk MR, ShukittHale B, Joseph JA. Blueberry supplementation improves memory in older adults. J Agric Food Chem. 2010;58(7):3996-4000.

46. Krikorian R, Nash TA, Shidler MD, Shukitt-Hale B, Joseph JA. Concord grape juice supplementation improves memory function in older adults with mild cognitive impairment. Br J Nutr. 2010;103(5):730-4.

47. Skarupski KA, Tangney C, Li H, Ouyang B, Evans DA, Morris MC. Longitudinal association of vitamin B-6, folate, and vitamin B-12 with depressive symptoms among older adults over time. Am J Clin Nutr. 2010;92(2):330-5

48. Kaczmarczyk MM, Miller MJ, Freund GG. The health benefits of dietary fiber: beyond the usual suspects of type 2 diabetes mellitus, cardiovascular disease and colon cancer. Metabolism. 2012;61(8):1058-66.

49. Mayeux R, Stern Y, Cote L, Williams JB. Altered serotonin metabolism in depressed patients with Parkinson's disease. Neurology. 1984;34(5):642.

50. Tarleton EK, Littenberg B, MacLean CD, Kennedy AG, Daley C. Role of magnesium supplementation in the treatment of depression: a randomized clinical trial. PLoS ONE. 2017;12(6):e0180067.

51. Milind P, Suman M. Eat tomato a day to keep depression at bay. Asian J Biol Sci. 2009:4(2):258-62.

52. Tomić M, Ignjatović $Đ$, Tovilović-Kovačević $G$, Krstić-Milošević $D$, Ranković S, Popović T, Glibetić M. Reduction of anxiety-like and depression-like behaviors in rats after one month of drinking Aronia melanocarpa berry juice. Food Funct. 2016;7(7):3111-20.

53. Sawamoto A, Okuyama S, Yamamoto K, Amakura Y, Yoshimura M, Nakajima M, Furukawa Y. 3,5,6,7,8,3', 4' -heptamethoxyflavone, a citrus flavonoid, ameliorates corticosterone-induced depression-like behavior and restores brain-derived neurotrophic factor expression, neurogenesis, and neuroplasticity in the hippocampus. Molecules (Basel, Switzerland). 2016;21(4):541

\footnotetext{
Ready to submit your research? Choose BMC and benefit from:

- fast, convenient online submission

- thorough peer review by experienced researchers in your field

- rapid publication on acceptance

- support for research data, including large and complex data types

- gold Open Access which fosters wider collaboration and increased citations

- maximum visibility for your research: over $100 \mathrm{M}$ website views per year
}

At BMC, research is always in progress.

Learn more biomedcentral.com/submissions 